\title{
Anna Gibbs \\ Writers, writing and writing programs in the information age: Code, collaboration and interdisciplinary connection
}

\begin{abstract}
This paper argues that writing programs need to consider forging more active alliance with the visual arts, on the grounds that the digital revolution is beginning to bring about changes that will see writers and artists (and technicians of different kinds) working together in collaboration more frequently than at present, and that new practices in creative research mean that we may have more in common with the visual arts than with other, traditional, disciplines when it comes to arguing politically for the value of what we do. This case is made by examining in detail selected instances of the work being written on 'complex surfaces' (Cayley 2005), new kinds of work being made with code, and the reconvergence of text with the visual in new media work.

Keywords: code, collaboration, interdisciplinarity, writing and visual arts
\end{abstract}

We see language marketed as an infantile commodity - a toy suitable for kids of all ages, because its plastic coating makes it safe to own and easy to use; nevertheless, we must imagine a more corrosive poetics (something vitriolic enough to dissolve such an acrylic veneer), and if we cannot distill this kind of acid, then let us concoct a more explosive poetics (something catalytic enough to detonate such an acetate finish). We need a lingual variety of gelignite or plastique - the kind of incendiary literature, written only by misfits, who have grown up, still dizzy from the fumes, after having melted a platoon of plastic armymen with a match. (Bök 2010a)

What does the information age mean for the teaching of writing in university writing programs? What demands does the present place on the kinds of teaching in these programs and on the way they conceive of both the work of writing and their relationship to other programs in the university? This paper sets out to address these questions by examining the changing cultural conditions under which writers are working; the growing importance of collaboration between writers and artists, scientists and programmers, the increasing involvement of forms of mediation (computer code, for example) in writing itself, and the reconvergence of text and image in new media work.

Over the last twenty years or so, practice across the various disciplines of the creative arts has been transformed by the engagement of artists, performers and writers with new technologies. The creative processes involved in new media 
art and writing are challenging older models of artistic production in which, for example, writing, painting and installation were conceived as separate disciplines. Many contemporary artists now work interdisciplinarily: they no longer specialize in one medium (photography, installation, artist books) or one mode (image, sound, writing, performance). At the same time, forms of authorship and writing agency are being reconfigured as writers collaborate with artists and software designers, and artists take up writing as part of their new media practices. Writing has become a form of computer-enabled experimentation with visual, sonic and material environments to be entered, explored and engaged with, and these environments are now also capable of exhibiting their own behaviours. The programmable nature of the computer facilitates the making of work that is interactive, or which might use algorithms or combinatorial processes to generate text. Writing may also migrate through forms of networked communication like wikis, blogs and listservs engendering collaborative communities. Margaret Simons explains that Google Wave, currently under development, is

a social networking and collaboration tool in which groups of any size can share content and collaborate on projects, communicating in a manner that is somewhere between blogging, email and instant messaging... Clearly, it changes what it means to write. Reading, and writing, become collaborative and social. There is no seclusion, no one-way flow between writer and reader. Everyone is involved, all the time. (Simons 2010)

As Simons also points out, Google Wave allows for readers' interventions even in the realtime process of writing. In this context of collaboration and emphasis on process at least as much as on product, the

traditionally delineated arts - literature, music, photography, fine art, architecture, graphics, etc. - struggle to cope with the reconfiguration of their media, or with a migration to complex new media which are suddenly shared, suddenly intercommunicable with those of artistic practices previously considered to be distinct. (Cayley 2002)

In some ways, this process of transformation recalls the intense period of modernist experimentation at the beginning of the twentieth century. The emphasis on syncretism and collaboration, the renewed interest in generative and procedural possibilities revivified in algorithmic work, the morphing of narrative into new forms, the emphasis on synthetic approaches to the arts and the sheer rapidity of innovation are all reminiscent of that period. Perhaps, however, there is one genre that could be seen as hinge between that period and this one, and between art and writing. That is the artist book, a form that could be seen as a precursor of so much that is now happening in the digital realm, especially as they conjoin writing with the methods and concepts of the contemporary visual arts.

In Nola Farman's Microbilia series, for example, a tiny typeface is used to draw the reader into an intimate connection with what is read, as simultaneously the literary is subverted by the shrinking of story to an absolute minimum in a series of recountings of mundane coincidences (Farman 2007). These small anecdotes refuse to add up to an overall narrative and instead comprise a kind of cartography of the quotidian in which intersecting situations momentarily give off an aura that illuminates them in their uniqueness even as they form part of the continuous flow of everyday life. These little coincidences reveal the extraordinary within the ordinary, what Georges Perec calls the 'infra- 
ordinaire', so that what he calls for, and what Farman writes, is an anthropology of the 'exotic within the endotic' (Perec 1989: 20).

Another of Farman's book works, The Tics of Appearance, is a witty commentary on Paul Virilio's The Aesthetics of Disappearance, the text of which is progressively disappeared by the artist until all that's left of Virilio's own argument are bursts of punctuation so that his aesthetics is reduced to an outbreak of involuntary spasms.
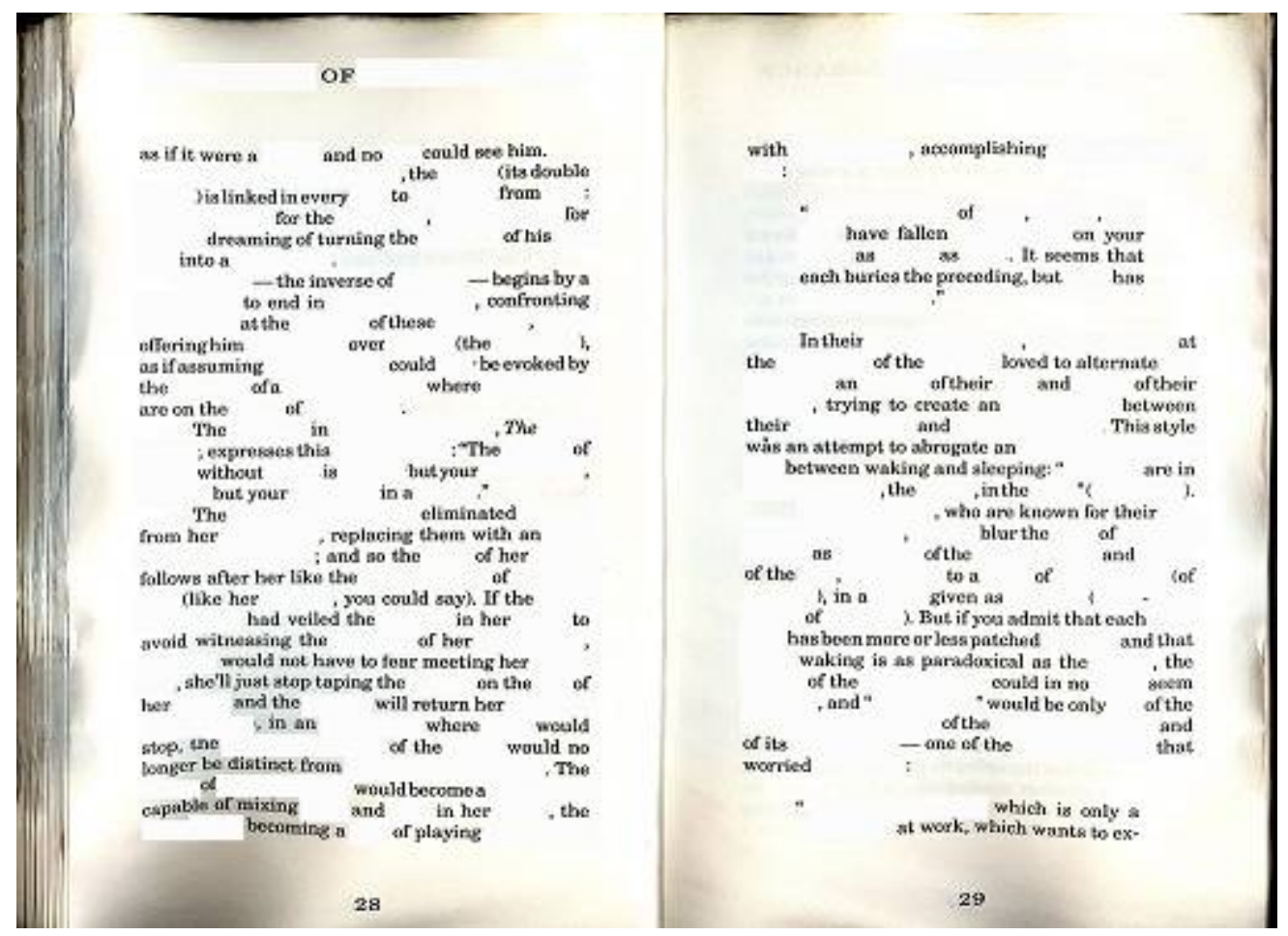

Published under the imprint of her Garden Path Press, Farman's books let you know immediately that they will lead you astray, and you might fall under the spell of a world where the usual rules don't apply. Book artists, she writes,

require their medium to go beyond the conceptual capabilities of the ordinary book; their art becomes a means for formal and informal experimentation with the materials and ideas that mix, match and entangle the contents and configuration of the book into a hybrid genre that pushes the idea of the conventional book to the limit. This is necessarily an experimental enterprise. (Farman 2007: 10)

In a different vein, Ruark Lewis' work Just For Nothing, sees the book provide a form of mediation between the script of Nathalie Sarraute's play Just For Nothing (Pour un oui ou pour un non) and its realisation as visual art.

Sarraute's work stages a verbal sparring between two childhood friends, now estranged. One is a solitary writer and the other is a prosperous and socially successful publisher. It's not so much a matter of what's said but of how it's said: of the minute, barely observable inflections and calibrations of speech, gesture and facial expression that indicate, for instance, that some one is lying or insincere and trying to mask it. These signals register in us automatically even as we collude with the speaker by not allowing ourselves to notice them, or if we do admit them to consciousness, to resist voicing a response which would make the unsaid explicit. Our almost imperceptible somatic registrations of response (internal sensation and movement) are what Sarraute calls 'tropisms' (also the title of her first book). They are both inexpressible directly in words and unnameable because often inchoate and difficult to grasp, and Sarraute's writing approximates them in 'images, metaphors, rhythms'.Lewis 
assists Sarraute's text to escape from the confines of the script - whose division into dialogue makes it hostile to reading for pleasure, since it's designed simply as a prompt for speaking aloud in performance. Lewis' 'new' work transposes the text into pages of prose bound in book form, where only a change in the colour of the type differentiates the speakers and the processes of silent reading are thereby facilitated. And then a further transposition is performed, as the text finds itself liberated from between the covers of the book only to be recaptured and framed in arbitrary segments on the gallery wall. Lewis' transcription of the text in different media produces an adaptation or translation, turning a performance script into concrete poetry on an almost architectural scale so that the alternating colours make the rhythms of asymmetrical turn-taking in the dialogue immediately visible in space rather than audible over time. Here the letters seem to float over the page as the voice floats in air when a script is performed, but they are confined under glass all the better to reveal their graphic dimension. This becoming-image of text immobilises it in a gridded space through which the visual rhythm moves, but in which each rectangle also produces a piece of excised text as a kind of concrete poem so that the flow of words also appears as a visual series in which, at one level, the more things change the more they stay the same. The drawings that accompany the transposed text - pen and ink monochromes -register complex calibrations of repetition and difference in a series of minute shifts across a bounded field to produce a mesmerising illusion of movement which challenges the gaze to hold its focus, or else releases it into an internal space. This technique, like the technique of transposition, is an analogue for Sarraute's own strategy for representing the minute ins and outs of everyday conversation in writing.

Nola Farman (2007) writes that,

[a]mongst its determinations, the page is a surface for inscription, a form for the moulding of light inviting a sculptural approach, a plane for implied depth as in a painting (the picture plane), and it is also an architectural space of structured dimensions contained by the shape of the book and the composition of its contents. The form of the book has the attributes of a work of sculpture. It occupies physical space... (Farman 2007: 10)

This facticity of books as objects contrasts with the virtual nature of the life inside them, for the book itself is a material form, as well as a space of imagination, and it is on this aspect of things that artist books often focus. The book is an object whose benign exterior often fails to hint at the potency of its contents. The book is also a container, albeit one whose internal volume is deeper than its external dimensions would ordinarily allow. This multidimensionality of the book means it lends itself to a working process that moves around within the frame of the page treating it now as a plane and now as a volume. But the conventional codex form of the book also organises pages in sequence, which makes them an ideal vehicle for constructing time as duration. Because of this, and because the pages need not be turned one at a time but can be riffled through very quickly, the book is also the perfect medium for proto-cinematic animation - as in Nola Farman's Flutter, in which the word 'flutter' is animated so it performs the motion to which it refers. The codex form also lends itself to investigation of the nature of seriality and the capacity of repetition to produce sameness and difference simultaneously. Jane Simon's wordless photographic work uses the codex form to explore the nature of seriality in which repetition and difference are both crucial and ends may be arbitrary, since the instances that furnish a series are in principle indefinite. Seriality is a feature of mass production, but the limited edition artist book insists on the handmade and draws attention metonymically to novelty, 
difference and detail within what is apparently the same. Simon's subjects are quotidian (everyday life is a paradigm of series which binds novelty in routine) and often suburban: houses, windows, steps, fences, adults and babies 'holding on' to each other as they go about their business. Her books work in the miniature: they are tiny and you have to lean in and look closely to distinguish the detail in her images. Paradoxically, though, it is as if we are looking at something that has been discovered under a microscope rather than at a shrunken world. Looking at her images is like looking at the views in the souvenir pens described by Raymond Roussel (1991: 229) or Vladimir Nabokov (in his autobiographical story 'First Love', cited in Ford 2001: 83) about which Simon has written in her work on the role of detail in image and writing (Simon 2007). There is something 'miraculous' about these images, as there is in the image described by Nabokov. The more you look the more you see, as if you are staring into an opening on the infinite. It hardly seems possible that such a universe could be contained here, and the tiny book, held in your hand, creates a sense of proximity and intimacy out of which it kindles wonder: you have a whole world in your hands. But then another paradox appears. The tiny portable book of images enables your secret possession of a world from which you would otherwise be excluded.

We tend to conflate books with story, since story books were what we first read or had read to us before we encountered the textbooks of our education, the inscrutable instruction manuals that beset our use of machines, the recipe books that program our cooking, or the travel guides that organise our tourism. In the autobiography of most readers, books are first of all vehicles for story, at first either in images or words, or combinations of both, before writing supersedes the image, prototypically in the genre of the novel. So it is that the series of associative links between the book, writing, story - and therefore the literary form a chain forged early. In A History of Reading, Alberto Manguel (1996) details the invention of silent reading, the concomitant shaping of the book as an object of a size and shape to be held in individual hands, and the creation of dedicated spaces such as the library, the study, the closet, the bed, and the reading 'corner' for private reading. In parallel with this privatisation of reading goes the creation of the complex imagined worlds that typify the novel form, and the possibility of the reader's absorption in them, as, from the words on the page, she conjures images 'under authorial instruction', as Elaine Scarry (1995: 1) has it - a 'dreaming by the book' (Scarry again) which actually unsettles boundaries between inner and outer worlds, in an interpenetrative process which creates another virtual, noncartesian space of possibility. Innumerable memoirs of reading life recall the private spaces of reading that made possible the absorption in virtual worlds, so that the book comes to represent what Walter Benjamin calls a space of 'archaic stillness' (Benjamin 1979: 62) - even if it details scenes of horror and violence.

This is a territory paradigmatically delimited by a writing made material by print, for which the book has over centuries proved to be an ideal container. But our capacity to read print has come at a cost, for print displaces another writing which we who are dependent on literacy no longer know how to decipher. This is the nonhuman writing of the world described by David Abrams:

The earthly terrain in which we find ourselves, and upon which we depend for all our nourishment, is shot through with suggestive scrawls and traces, from the sinuous calligraphy of rivers winding across the land, inscribing arroyos and canyons into the parched earth of the desert, to the black slash burned by lightning into the trunk of an old elm. The swooping flight of birds is a kind of cursive script written on the wind; it is this 
script that was studied by the ancient "augurs", who could read therein the course of the future. (Abrams 1996: 95)

Artist Bronia Iwanczak's Swarm recalls the 'locust swarms of print' which Benjamin imagines destroying the 'archaic stillness' of the book (Benjamin 1979: 62) and the kind of imaginative understanding such stillness might open. At first glance, Iwanczak's typography has the regularity of the lined page and seems to solicit reading, but this is an alphabet produced by the imprint of a cob of corn, and the closer one looks, the more irregularity appears within the regularity while the initial illusion of legibility recedes.

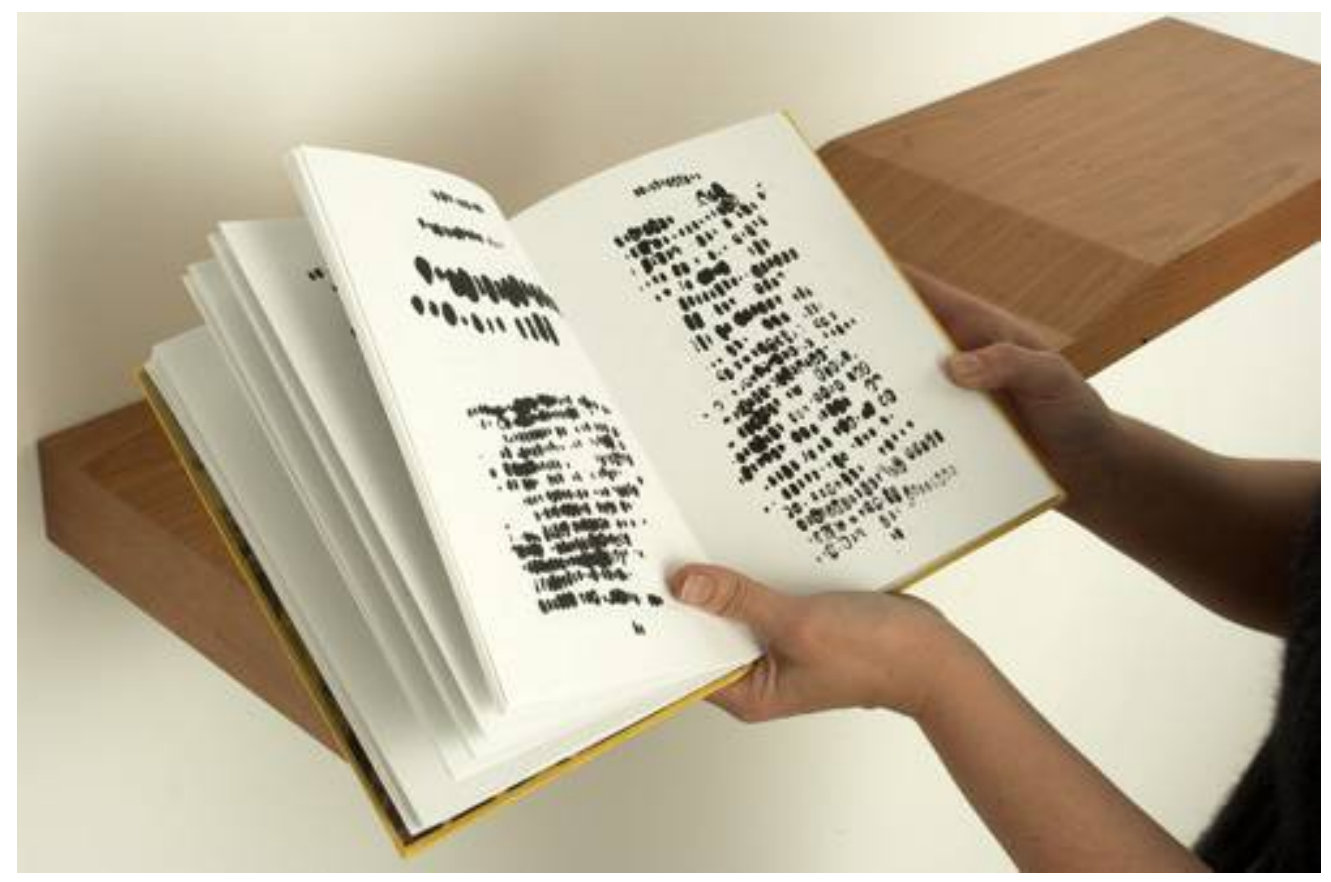

What then are these strange ciphers? What syntax is this? It is as if an original typography has been weathered away to the point where it now appears only as abstraction: the idea of type, minus the type itself. But in fact this is the imprint of a prototype: the use of a corn cob suggests the genetic engineering to which corn, probably more than any other plant, has been subject, so ubiquitous is it in all kinds of processed food. If we no longer know how to read the imprint of the world in the sense which Abrams describes, we have learnt to decipher the genetic code, to read DNA, and to write it. But as Iwanczak's title suggests, this may be knowledge with runaway consequences, producing the very disaster it was designed to stave off. Far from destroying the contemplative stillness of the book, Iwanczak renews it even as her work is redolent of a melancholy which seems to mourn the loss of our capacity for other kinds of reading.

This transformation, however, began not with the invention of the computer, but well before it, with the rise of the mass media in its first avatar as the newspaper. Newspapers in turn produce reading publics which become targets for advertising in the age of mass production. Walter Benjamin, a peerless and prescient commentator on the profound transformations inaugurated by new media, writes that

[p]rinting, having found in the book a refuge in which to lead an autonomous existence, is pitilessly dragged out onto the street by advertisements and subjected to the brutal heteronomies of economic chaos. This is the hard schooling of its new form. If centuries ago it began gradually to lie down, passing from the upright inscription to the manuscript resting on sloping desks before finally taking to bed in the printed book, it now begins just as slowly to rise again from the 
ground. The newspaper is read more in the vertical than the horizontal plane, while film and advertisement force the printed word entirely into the dictatorial perpendicular. (Benjamin 1979: 62)

As, one might add, does the computer screen. The kind of fluid, flexible, moving writing enabled by digital platforms seems to have been foreseen by Benjamin when he writes that

$[t]$ he typewriter will alienate the hand of the man of letters from the pen only when the precision of typographic forms has directly entered the composition of his books. One might suppose that new systems with more variable typefaces would then be needed. They will replace the pliancy of the hand with the innervation of commanding fingers. (Benjamin 1979: 62)

What Benjamin elides here is the age-old reciprocity between writing and drawing, 'its problematical opposite, and unacknowledged twin', as Martine Reid (1994: 8) terms drawing. The legible, as she says, is always in danger of reverting to what is simply visible, 'mere drawing'. This is because as 'it follows the train of thought to which it gives body and movement, the writing process comes across as a work-form that is forever on the point of drifting off course' (Reid 1994: 8). Reid points to the number of writers whose handwritten manuscripts contained extensive drawings lost to the publication process and the standardisation of the book: Flaubert, Colette, Valéry, Stendhal and Artaud among them.

Artist Liz Day's 'On the Origin of Ideas', an ongoing art project documenting the notebooks of creative people across the disciplines, including those of fellow artists Sarah Goffman, Lisa Andrew, Maria Cruz, Elizabeth Pulie, Mishka Borowski and Sadie Chandler (among others) sees the artist working as archivist, librarian, collector, curator, researching a research in which books are tools of process where sketches and diagrams are made to talk to words and words to images through caption, notation, description and elaboration.

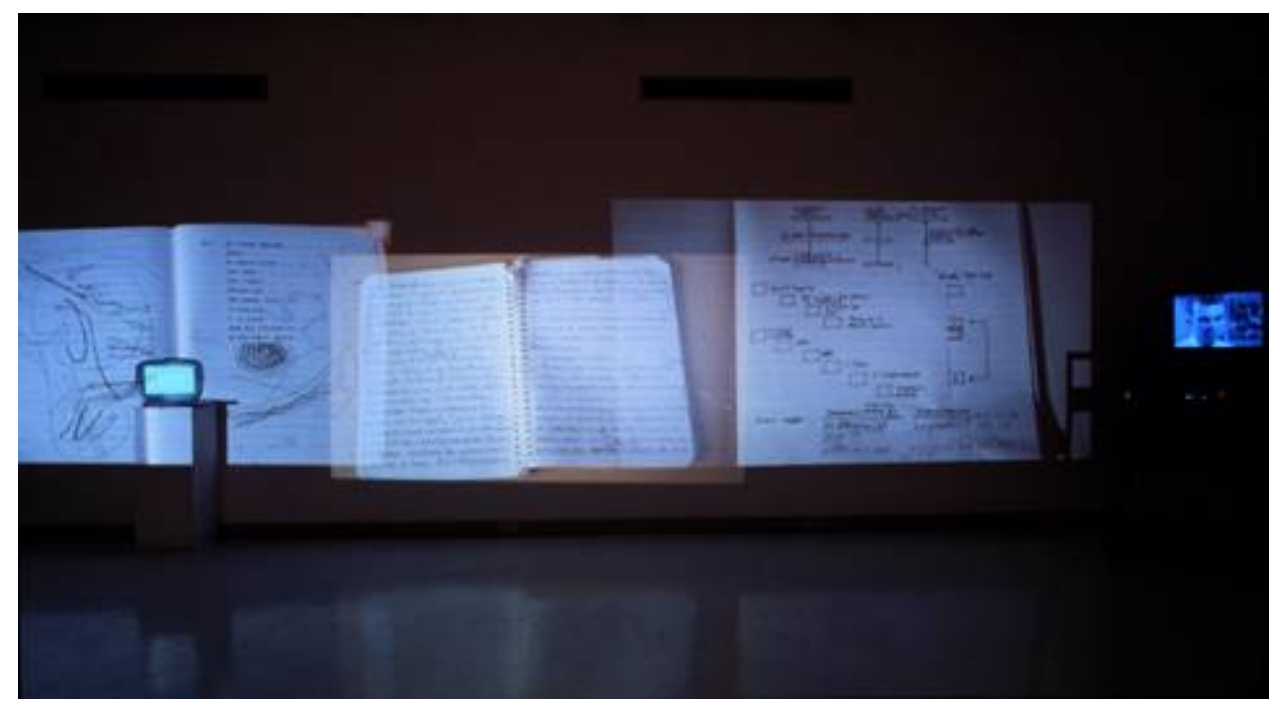

This is a process of to and fro in which thought is fleeting, now visual, now verbal, or hovering inchoate between the two, in the space of translation between them. Here a sketch is the hinge between words and images - a sketch is a rough embodiment, a gesture towards something. Perhaps the gesture transmits thought as it does the sensation that necessarily accompanies it - or perhaps it produces it so that the notebook can be conceived as a space of action which produces thought at the same time as it makes it material. Because looking at these signs provokes an abbreviated mimetic response - a repeat of 
the same sensation - in the body, they work as aids to corporeal memory for the artist. To use a notebook is to return writing to the body through the hand. Handwriting links letters separated by type and turns writing into a kind of drawing, since it is no longer confined to regular lines running horizontal and unidirectional across the page, but can take place in circles and eddies, can drift like a current to follow the musical or rhythmic contours of thought, can turn back on itself to reflect, cancel out, write over; can take a precipitous drop into vertiginous space. The page, in other words, is no longer a two-dimensional surface but a complex topology with an indeterminate number of dimensions. While the creation of works in digital media may restore the ductility between writing and drawing, this may be more for the reader of such work than for its producer, for whom it is mediated by the process of learning how to write one's one code, or how to use readymade software, or perhaps how to work with a collaborator who can do those things.

The role of type, however, is usually to function as a kind of invisible support for meaning - we look through it to the words it composes. But typography in the artist book or in digital media may instead make use of its graphic dimension, becoming a vehicle for the reproduction of activation contours to attract the eye to the page and make visible something about its contents in advance of reading. More than this, they make the writing surface a thing, turning it from convenient vehicle of story (for example) into a textual object. In this case, because it's impossible to look and to read at the same time, the reader oscillates between these two modes of apprehension. The history of type has always been characterised by a tension between characters as drawings (the plethora of typefaces bears witness to this) and characters as signs, as JeanGérard Lapacherie (1994) points out in his essay on the topic. Writers especially early in the twentieth century - like Reverdy, Queneau, Valéry, Leiris, Apollinaire, as well as the Futurists, Dadaists and Surrealists have often been conscious of this, and have experimented with it in their own work: though works of this nature are often treated as marginal to the mainstream by the literary world.

The keyboard has still not succeeded in alienating the hand from the pen, because it simply doesn't permit the spontaneity of gesture which handwriting (like drawing and painting) allows, but we might still wonder if the moment is approaching when we no longer know how to read the signs of human gesture so schooled have we become by the digitised smoothness of the corporate logo? Artist Bronia Iwanczak's Eight Glasses of Water a Day is an edition of eight books composed of pages of blue watercolour over which a glass of water has been spilled a page at a time so that monochrome patterns produced form a series in which each differs a little from the last. 


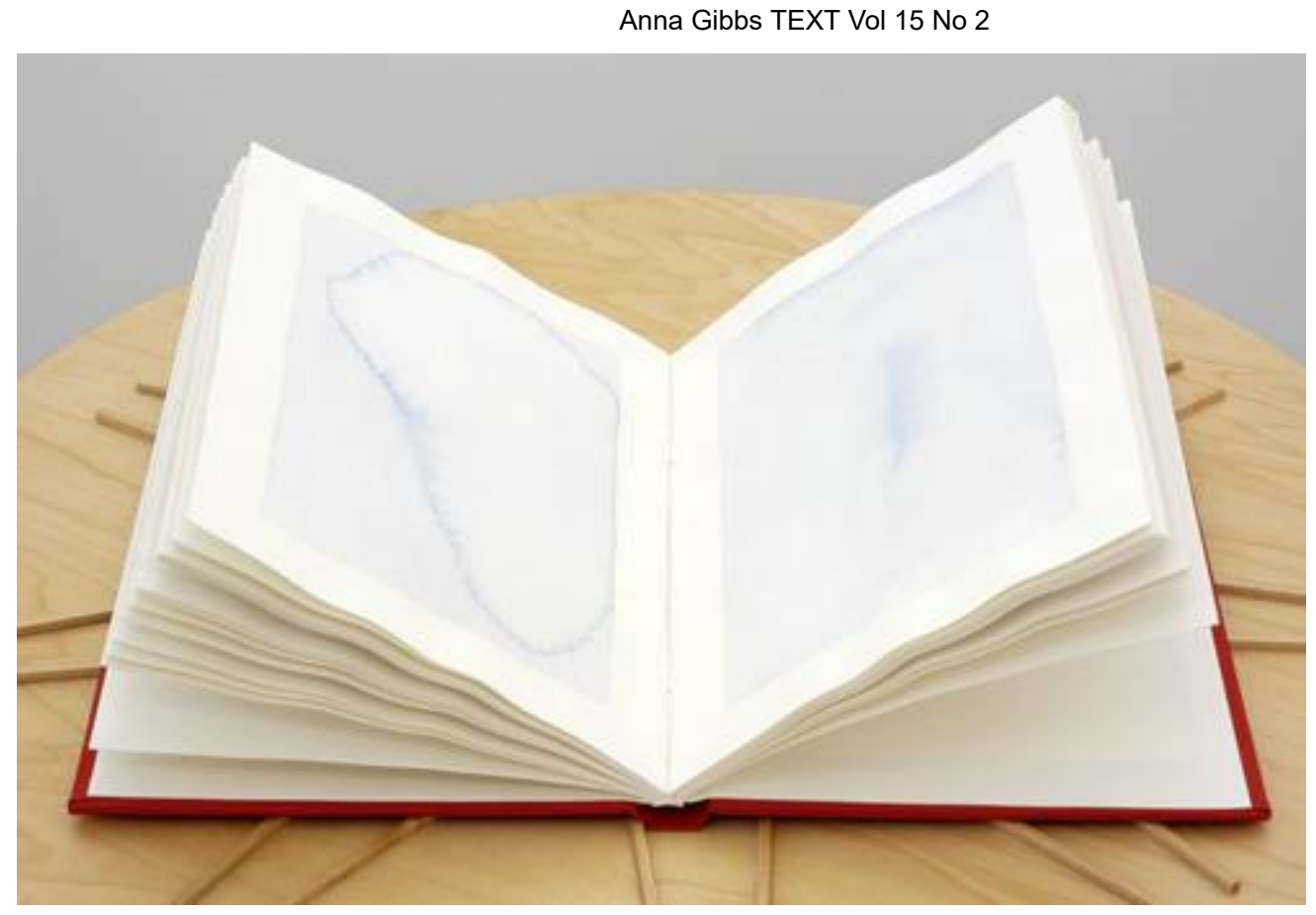

Because they are bound as pages in a book, this sequence of watery blue stains seems to suggest faded ink, damage by time and weather, the possibility of legibility effaced. Have we lost the art of reading the trace of time or the trace of gesture? Or do we absorb some knowledge below the level of consciousness as we contemplate these porous pages which have also absorbed the artist's gesture, the water she poured on them, and the colour blue? What is the difference between reading and contemplation? Eight glasses of water a day: what we are supposed to consume for optimum health has instead been spilled in a gesture that enacts at once waste and excess and in doing so, reveals their mutual implication.

Perhaps Benjamin underestimates the extent to which, if the word is becoming image, the image has undergone a reciprocal transformation. Words have long been essential to painting, first in the form of myth or religious allegory, and more recently in the form of critical discourse, as WJT Mitchell (2005) points out, and even "photography is typically so riddled with language, as theorists from Barthes to Victor Burgin have shown, that it is hard to imagine what it would mean to call it a purely visual medium' (Mitchell 2005: 260). For Benjamin the book is in any case - even as he was writing in the early twentieth century - an obsolete form, an 'outdated mediation between two different filing systems', the card index of the researcher and that of the scholar who uses the book as a source (Benjamin 1979: 62).

But the book has not been entirely superseded, and we are now living in a period in which oral, alphabetic and photoelectronic cultures are all contemporary. This is a situation, as Steven Connor writes, which 'disclose[s] the complex historicity of all writing' and for which 'a model of cultural relationship based on topology rather than succession, on palimpsest rather than erasure: on overwriting' is required (Connor 1999). This is also a model for contemporary practice, where writers very often work in more than one medium. And the possibility of working in a wide variety of media is beginning to play a very important part in inciting students' desire to write as well increasingly shaping their writing practices. They are more and more interested in writing across the different media in which, through 'text' (as the technological - that is, alphabetical - communication of traces of speech and thought), writing persists and flourishes. These new spaces and platforms for writing include GPS-enabled locative works (Chris Caines' work is a good example [1]); immersive environments (sensors, video etc as in the work of Peter Charuk [2]); games and staging (as in Jason Nelson's work [3]). What 
they have in common, though, is what Maria Angel and I have referred to elsewhere as the 'becoming-image of writing', a contemporary process of reconvergence of image and text which also draws on previous histories of illustrated manuscripts, artist books and text-based art (Angel \& Gibbs 2009).

This process is also evident in the work of Australian writer Mary Anne Breeze (aka Mez) [4]. Mez's work can be seen as writing becoming art as she invents Mezangelle, a new language that includes elements of computer code made to work as text readable to humans. In Mezangelle these graphic elements 'colonise' the visible surface of the work - the look of the text - which aims to render visible what usually remains invisible, acting in secret 'below' the level of the text it generates, animates and makes legible. John Cayley writes that code functions 'without being observed, perhaps even as a representative of secret workings, interiority, hidden process' (Cayley 2002). Thus, in addition to its engagement with writing as image, Mez's work also raises the question of what it means for writing to be generated from code. As Gutierrez et al (2009) point out, 'the presentation layer is a deception, a challenge to the very division of layers, a revelation that hides'. Moreover, they continue,

...we are compelled to execute the presented code by tracing out its logic. We must take the place of the compiler with the understanding that the coding structures are also meant to launch allusive subroutines, that part of our brain that is constantly listening for echoes and whispers. To produce that reading, we have had to execute that poem, at least step through it, acting as the processor... Where traditional poetry establishes identity through I's, Mez has us identify with a system ready to process the user who is not ready for the fifth world, whatever that may bring. (Gutierrez et al 2009)

More generally, codeworks like Mez's highlight the complexities both of agency and address that print-based technologies allow us to overlook. Cayley usefully reminds of the complexity of address inherent in codeworks, which are not simply language displayed as text on a screen, but also comprise

composed code ... addressed to a processor, perhaps also addressed to specific human readers (those who are able to "crack" or "hack" it); while the text on the screen is simultaneously? asynchronously? addressed to human readers generally. (Cayley 2002)

Equally complex, however, is the question of agency in the process of writing, that is, of addressing text. The fantasy that what unites and underlies all new media forms is software, which simply comes to replace an intentional subject, has been termed 'sourcery' by Wendy Chun (2008: 229). This fantasy, she points out, ignores the extent to which agency and authorship are actually distributed among hardware, software, creators of programs and code, and readers of those and literary texts. In this context, as Cayley sees, new relationships are 'constituted by artistic practice - between a newly problematised linguistic materiality and represented content'.

Mediation [by programming] can no longer be characterised as subsidiary or peripheral; it becomes text rather than paratext. Criticism of code-making in this context becomes even more important and central than, for example, the criticism of instrumentation or interpretation in musical recital. (Cayley 2002) 
More importantly, though, mediation becomes collaboration not only between writers on the one hand and code or computers on the other, it becomes a collaboration between human and non-human actors which gives rise to entirely new conditions.

Nowhere is this more evident than in the current project of writer Christian Bök, which involves work not with computer code, but with genetic code. Bökis a Canadian writer who sees his work as a series of 'conceptual experiments' (Bök 2008: 227). This is a crucial formulation, since it recalls the 'conceptual art' of the 1960s and 70s - especially the work of the British group Art \& Language which, resonating with the linguistic turn in philosophy, made 'visual' art using language as their primary medium, seeing as secondary the material means of its presentation. But it also refers to Pataphysics, that 'poetics of an imaginary science' conceived by Alfred Jarry as parody in the late nineteenth century and elaborated into a conceptual principle by Oulipo member Raymond Qeneau and others throughout the twentieth century and into the twenty-first, where it is associated with a loose, largely US-based, collection of 'conceptual' writers whose use of Oulippean constraints and other 'procedures' - especially those associated with appropriation and other mimetic modes - could be seen as a means of liberating expression from subjectivity(rather than being simply 'against expression', as the title of a new anthology of conceptual writing edited by Craig Dworkin and Kenneth Goldsmith (2011) has it) as well as a means of experimenting with ideas, especially ideas about language itself.

Bök's first book, Crystallography (1994) is a collection of poems which treats the language of geology and geological concepts themselves as a series of metaphors or 'conceits' for writing (the term itself literally means 'lucid writing'). His best known book, however, is his second, Eunoia (2001). 'Eunoia', as he explains, 'is the shortest word in English to contain all five vowels' and means 'beautiful thinking' (Bök 2001: 103). Written under a kind of reversal of an Oulippean constraint (the lipogram) so that rather than suppressing a single letter (as Perec's La disparition, for example, suppresses the letter 'e') each of the five chapters in the title piece deploys only words using a single one of the vowels in turn, and the letter ' $y$ ' is suppressed throughout. Like La disparition (in which a story about the missing letter enacts the constraint at the level of 'plot') Eunoia fictocritically addresses the nature of writing as an artform, that is, as a literary endeavour, by adhering to other rules about the formal construction of sentences which heighten the 'poetic' effects of the work to bring 'beautiful thinking' performatively to life. The persistent, almost alchemical, use of internal rhyme entailed by one such rule helps create the impression that each vowel has its own characteristic affective colour or feeling tone given off as it separates from the base metal of the alphabetic material. Other works in the collection make use of different constraints, but all follow, in different ways, the fictocritical 'rules' of reflexivity and the mutual entailment of form and content. This is a writing beyond genre, neither precisely fiction nor exactly poetry, and yet partaking of qualities of both.

Bök's current project, The Xenotext Experiment, aims to extend writing 'beyond the formal limits of the book', and in so doing gives the term 'life-writing' an entirely new meaning. Recognizing code as the basis of life, Bök is working in collaboration with geneticist Stuart Kauffman and others to create an example of biophysical writing, or what he calls 'living poetry'. He plans to do this by using a 'chemical alphabet' to encrypt a poem into a sequence of so-called 'junk' DNA which will then be transplanted back into the genome of a bacterium. The poem will take the form of a set of instructions so that the bacterium which henceforth 'expresses' the text will then begin to produce a 
new protein, which (because it is composed from the original chemical alphabet) will comprise a second text. This entails devising a code 'which links the letters of the English alphabet to the genetic nucleotides (adenine, cytosine, guanine and thymine, or ACGT). Each English letter will correspond to a grouping of three of these nucleotides (a tri-nucleotide sequence or "codon")' (Bök 2010b).

What Bök is doing here, then, is a work of bio-engineering which turns a lifeform (in this case a bacterium) into a durable archive for storing text - one which might in fact outlast humankind. This is not entirely without precedent. As Bök reports, his own project is inspired by several previous projects of lifewriting. Cybernetic expert Pak Wong has already encoded into the DNA of a bacteria the song lyrics to 'It's a Small World After All', and multimedia artist Eduardo Kachas encoded a verse from the Bible into a strand of DNA, inserted this into a microbe, and exposed it to doses of mutagenic radiation. As Bök explains, Kac sees this process as a kind of textual editing through mutation, in order to 'foster an unguided, aleatory message in a more innovative form, rather than accept the dominant, biblical passage in its last inherited form' (Bök 2008: 228). (Paradoxically, the bacterium chosen for this purpose-Deinococcus radiodurans - is said to be one of the most resilient organisms known to biologists. It is in fact what is known as an 'extremophile', a life-form that has evolved to survive in extreme environments - the very salty waters of the Dead Sea; the boiling waters of thermal vents; or even in nuclear waste). Kac's and Bok's projects both address the problem of the instability and unreliability of technological platforms as storage facilities, and the associated problem presented by the emergence of an aesthetic based on protocols of 'choice' and personal expression which renders text and narratives unstable, since the reproducibility of text read - or produced - through moment to moment choices of links and pathways can never be guaranteed. At the limit, this poses more general problems for the reproducibility, stability and transmission of memory and knowledge. But where Kac makes a virtue of this instability, Bök devises a pataphysical 'imaginary' solution to it (Bök 2008: 230). Bök's work aims to turn the bacterium into a machine for actually writing text. This process may in fact have unintended consequences, because 'junk' DNA is probably not useless, but is in reality simply DNA whose purposes geneticists don't yet understand.

Bök's work wants to be situated in a large interdisciplinary field whose work claims effectivity beyond the literary, since he envisages that the project might eventually give rise to a 'secure method for transmitting secretive documents', but might also find a way to "watermark" cells so as to track the movement of either microbial diseases or botanical products' (Bök 2008: 230). He also anticipates that the work will demonstrate the possibility of using

nanoscopic, biological emissaries ... to transmit messages across stellar distances or even epochal intervals so that, unlike any other cultural artefact so far produced (except perhaps for the Pioneer probes or the Voyager probes), such a poem, stored inside the genome of a bacterium, might conceivably outlast terrestrial civilization itself, persisting like a secret message in a bottle flung at random into a giant ocean.(Bök 2008: 231)

Bök's latest work exemplifies what I predict will be an emerging tendency, that is, for writers to work as part of interdisciplinary research teams. This is a trend that is already apparent in the visual arts. In Australia this is exemplified in centres like Symbiotica at the University of Western Australia where Orlan created a harlequin coat made of grafted skin cells and where other artists are working on various nanotechnology, biology and other science projects. Or the 
Centre for Memory, Invention and Imagination at Deakin University, where artists are involved in a series of projects on climate change and environment which aim to generate different kinds of what Centre Director Paul Carter has called 'place-based knowledge' (Carter 2010: 2). At my own university University of Western Sydney - one might cite Stelarc's Talking Head and Thinking Head projects [5], carried out in collaboration with researchers in the MARCS lab (see http://marcs.uws.edu.au/).

No doubt the form collaboration takes is different in all these sites, but overall this is a way of working that is not so familiar to writers, who seem to be more attached than contemporary artists to the idea of the freedom of the imagination and the autonomy of the artist as an expressive subject. But it is a way of working that explicitly recognizes what is always implicitly the case but usually unacknowledged in any meaningful way: that creativity is always collaborative, and understands that intentionality and agency are shared - albeit unevenly between various human actors and nonhuman ones. It is a way of working that is avowedly experimental, that engages in a heuristic process of trial and error to see what happens: one that relinquishes teleological certainties in favour of surprise and unintended outcomes. It acknowledges that writers - or any individual as such - are not at the origin of invention but in the middle of it, that is, that writers are relays, or mediators. I'm using the term 'mediator' in the deleuzian / latourian sense in which a mediator is a participant in a deleuzian becoming, that form of creative mimesis in which the wasp and the orchid (to use Deleuze and Guattari's famous example) each work to translate forces from one world to another. Neither is a simple go-between or intermediary: each performs work, and each is transformed in the process. That is to say, they act as complex switching points, rather than sources or origins of action. Instead the mediator might be seen as 'a moving target of a vast array of entities swarming toward it' (Latour 2005: 46). These switching points redistribute agency as they translate forces from one system to another. In this process of transduction performed by mediators, things are lost, ignored, left behind or discarded, as they always are in translation. But equally, things are found, discovered, or created.

To work as part of a collaborative interdisciplinary team is to think writing beyond individual expression and beyond representation: as a way of doing, of realizing, of research and invention. Bök sees his own project addressing the way in which, as he puts it, 'the modern, social milieu has now taken for granted that the discursive structures of epidemiology (as seen, for example, in such notions as "viral marketing" or "viral computing")' which he speculates might also 'apply to the transmission of ideas throughout our culture' (Bök 2008: 231). One could take this to mean that his work in progress is a literalisation of this state of affairs (except, of course, that he is working with bacteria rather than viruses). Or one could understand it as an oblique reference to Richard Dawkins' (1976) theory of memes, those cultural forms or practices (ideas, know-how, fashion, melodies, etc) that he conceives as replicating by using people as carriers to ensure their own survival, just as genes do when they transmit themselves from generation to generation, transforming the individuals through which they express themselves in the process.

So what, then, are the implications of all this for writing programs today? What should determine the placement of writing programs, in relation to other departments, I think, is probably their method: that capacity to engage with other modes of knowing without becoming discipline bound that, paradoxically for my argument, Roland Barthes saw as the particular property of the literary, which doesn't fix or fetishize any particular knowledge, but instead works in the interstices of disciplinary knowledges like physics, biology, anthropology or, for that matter, literary theory by a bias of 'indirection', so that the 
'knowledge it mobilises is neither whole nor final: literature never says it knows something, but that it knows about something; or better, that it knows something about it...' (Barthes 1978: 18-19, my translation). What it especially knows something about, Barthes goes on, is the way language works us as we work it - because literature "performs language rather than merely using it: through writing, literature, knowledge reflects incessantly on itself, by way of a discourse which is not epistemological, but dramatic' (Barthes 1978: 19).

However, in a further twist of paradox, this function may not any longer be confined to the kind of writing we habitually think of as literature. As Marjorie Perloff puts it,

...perhaps poetic "uniqueness" in our postromantic age is less a matter of individual expression than of sensitivity to the language pool on which the poet draws in re-creating and redefining the world as he or she has found it... The poetic thus functions as a heightened form of social and cultural critique, a way of defamiliarizing not so much what is seen, as was the case in modernist poetry, as what is known and what is actually done. (Perloff 1996: 187)

While it is commonplace now to think of literary writing as concerned with message and meaning (and hence reading as primarily concerned with interpretation), I want to argue, in line with the work of those textual theorists (especially Shoshana Felman and Judith Butler) who have productively taken up speech act theory and traced its implications for thinking the literary, that writing is primarily about doing, and that literary texts have their own special ways of doing. Anthropologist of art Alfred Gell calls this special mode of doing 'enchantment' (Gell 1984: 96) - though in his work it characterises the action of all, not only literary - art. In relation to this, meaning may in fact be secondary in the sense that literary texts (and other artworks of various kinds) must evince 'a certain cognitive indecipherability' (Gell 1984: 96), and, as Nicholas Thomas elaborates in his introduction to Gell, 'that they tantalize, they frustrate the viewer unable to recognize at once "wholes and parts, continuity and discontinuity, synchrony and succession' (Thomas in Gell 1984: $3)$.

Barthes speaks of 'literature' as a thing, the poetic or novelistic object as print on a page, but perhaps, in the optic opened by Perloff, we might better speak of the literary, as a kind of linguistic and rhetorical work in writing. We have been used, on the whole, even now, to thinking of writing and the literary text mainly in terms of debates over its representative function, but I think it is urgent now to understand it in terms of its communicative and affective dimensions, dimensions which persist - or insist - across genres, forms and media, from the book (whether of fiction, poetry, history or philosophy) through theatre, film, television, the internet and mobile phones.

Given the shape of the field I have attempted to chart above, I think writing programs should be moving towards more active alliances with the broader field of creative arts, including the visual arts. While the disciplines of English or textual studies, art history and theory and theatre and performance studies are all important, and one would want to see courses in them (as well as philosophy, history, the sciences and informatics) being taken by students in the practice-based arts, I think it has become urgent for creative arts programs to move into a new space of interdisciplinary arts practice. In particular, we need to militate against the rigid disciplinarianism enforced by the ERA when it ranks journals in disciplinary silos. But such a grouping would also give us all a stronger base for provoking change in the $\mathrm{ARC}$, where at present the creative 
arts are not at all well served. Perhaps even more importantly, though, to move in this direction would be to better position writing programs to engage with the migration of writing from the page out into a wider world.

\section{Notes}

1. Caines' University of Technology, Sydney biographical note states 'Chris works at the intersection of cinematic practices \& transformational new technologies with an interest in what these hybrids can add to the art of storytelling. His work in short film \&post production has been focused around utilising the possibilities of new imaging \& visual fx technologies as a part storytelling language itself. Alongside this work he has been developing online interactive fictions since the early nineties exploring the relationships between formal hypertext fiction and the language of web conventions that surround it. In recent years he has been producing site specific fiction \& documentary projects utilising mobile phones and other forms of location aware media.' See http://datasearch2.uts.edu.au/fass/staff/listing/details.cfm?StaffId=1610 return to text

2. See the artist's website for examples of his work: http://www.petercharuk.com/ return to text

3. See Nelson's website at http://www.secrettechnology.com/ for examples of his work return to text

4. See examples of Mez's work at http://www.hotkey.net.au/ netwurker/ return to text

5. See the artist's website, http://www.stelarc.va.com.au return to text

\section{Works cited}

Abrams, D 1996 The Spell of the Sensuous. New York: Vintage return to text

Angel, M \& A Gibbs 2009 'On Moving and Being Moved: the corporeality of writing in literary fiction and new media art', in H Groth and A Uhlmann (eds) Literature and Sensation. Newcastle: Cambridge Scholars return to text

Benjamin, W 1979 One Way Street. London: NLB return to text

Barthes, R 1978 Leçon. Paris: Seuil return to text

Bök, C 2010a 'Virtually Nontoxic', Christian Bök

http://epc.buffalo.edu/authors/bok/virtually.html (accessed 21 September 2011) return to text

Bök, C 2010b 'Christian Bok on The Xenotext Experiment', CBC Books(23 June)

http://www.cbc.ca/books/2010/06/christian-bok-on-the-xenotext-experiment.html (accessed 22 October 2011) return to text

Bök, C 2008'The Xenotext Experiment', scripted, 5, 2 (August): 227-231 return to text

Bök, C 1994 [2003] Crystallography. Toronto: Coach House Books return to text

Bök, C 2001 Eunoia. Toronto: Coach House Books return to text

Carter, P 2010 Ground Truthing: Explorations in a Creative Region. Perth: University of Western Australia Publishing return to text

Cayley, J 2002 'The Code is not the Text (unless it is the Text)', Electronic Book Review www.electronicbookreview.com/thread/electropoetics/literal (accessed 22 October 2011) return to text

Cayley, J, 2005 'Writing on Complex Surfaces', dichtung-digital http://www.dichtungdigital.org/2005/2-Cayley.htm (accessed 22 October 2011) return to text 
Connor, S 1999 'Modernism and the Writing Hand', Steve Connor

http://www.stevenconnor.com/modhand.htm (accessed 22 October 2011) return to text

Chun, WHK 2008 'On “Sourcery,” or Code as Fetish', Configurations 16, 3 (Fall): 299-324 return to text

Dawkins, R 1976 The Selfish Gene. Oxford: Oxford University Press return to text

Dworkin, C and K Goldsmith 2011 Against Expression: an anthology of Conceptual Writing. Chicago: Northwestern University Press return to text

Farman, N 2007 The Humours of the Artists' Book, unpublished PhD, University of Western Sydney return to text

Ford, M 2001 Raymond Roussel and the Republic of Dreams. Ithaca: Cornell University Press return to text

Gell, A 1984 Art and Agency(intro N Thomas).Oxford: Oxford University Press return to text

Gibbs, A 2010 ‘After Affect: Sympathy, Synchrony and Mimetic Communication’, in M Gregg \& G Seigworth (eds) The Affect Reader, Durham: Duke University Press

Gutierrez, JB, MC Marino, P Gervás \& LB Castanyer 2009 'Electronic Literature as an Information System',Hyperrhiz.06 Special Issue: Visionary Landscapes (Summer), http://www.hyperrhiz.net/hyperrhiz06/19-essays/74-electronic-literature-as-an-informationsystem (accessed 22 October 2011) return to text

Lapacherie, J-G 1994 'Typographic Characters: Tension Between Text and Drawing', Yale French Studies, 'Boundaries: Writing and Drawing', 84: 63-77 return to text

Latour, B 2005 Reassembling the Social: an introduction to actor-network theory, Oxford: Oxford University Press return to text

Manguel, A 1996 A History of Reading. London: Harper Collins return to text

Mitchell WJT 2005 'There Are No Visual Media', Journal of Visual Culture 4, 2 (August): 257266 return to text

Perec, G 1989 L'infraordinaire. Paris: Seuil return to text

Perloff, M 1996 Wittgenstein's Ladder: poetic language and the strangeness of the ordinary. Chicago: University of Chicago Press return to text

Reid, M 1994 'Editor's Preface: Legible/Visible', Yale French Studies, 'Boundaries: Writing and Drawing', 84: 1-12 return to text

Roussel, R 1991 Raymond Roussel: Selections From Certain of His Books (trans J Ashbery, H Matthews, A Melville \& M Sorrell). London: Atlas Press return to text

Scarry, E 1995 'On Vivacity: The Difference Between Daydreaming and Imagining-UnderAuthorial-Instruction', Representations 52 (Fall): 1-26 return to text

Simon, J 2007 Looking Through Cultural Studies, unpublished PhD thesis, Gender and Cultural Studies, Sydney University return to text

Simons, M 2010 'Reading in an age of change: Margaret Simons on text in the electronic world', Overland 198 http:/overland.org.au/previous-issues/issue-198/feature-margaretsimons/ (accessed 22 October 2011) return to text

Stiegler, B 2009 'Le Mépris - Contempt' Culture Action Europe http://www.cultureactioneurope.org/component/content/article/548-le-mepris-contempt? lang=en 
Associate Professor Anna Gibbs supervises postgraduate students in Writing, Textual Studies and Visual Arts in the Writing and Society Research Group and the School of Communication Arts at the University of Western Sydney. She is currently working on an ARC funded scholarly project, 'Creative Nation: Writers and Writing in the New Media Culture', with Dr Maria Angel (UWS) and Professor Joe Tabbi (University of Illinois, Chicago).

\section{TEXT}

Vol 15 No 2 October 2011

http://www.textjournal.com.au

Editors: Nigel Krauth \& Kevin Brophy

Text@griffith.edu.au 